\title{
Chronic Liver Disease and the Risk of Osteoporotic Fractures: A Meta-Analysis
}

Diego F. Hidalgo ${ }^{1}$, Boonphiphop Boonpheng ${ }^{2}$, Sehrish Sikandar ${ }^{3}$, Lubna Nasr ${ }^{4,3}$, Jessica Hidalgo ${ }^{5}$

1. Geriatrics, Jackson Memorial Hospital, University of Miami, Miami, USA 2. Internal Medicine, East Tennessee State University, Johnson City, USA 3. Geriatrics, Miami Geriatric Research Education and Clinical Center Veterans Successful Aging for Frail Elders (VSAFE), Miami, USA 4. Geriatrics, University of Miami Miller School of Medicine, Miami, USA 5. Internal Medicine, San Francisco de Quito University, Quito, ECU

Corresponding author: Diego F. Hidalgo, dhidalgo014@gmail.com

\section{Abstract \\ Introduction}

Chronic liver disease (CLD) causes more than 1 million deaths every year and remains a pandemic in the last decade affecting more than 600,000 patients in the United States. Previous studies found patients with CLD had increased risk of osteoporosis, so fractures were inferred to be complications of this condition. The aim of this meta-analysis is to summarize the best evidence that correlates CLD patients and the risk to develop osteoporotic fractures versus control patients without CLD.

\section{Methods}

A review of the literature using MEDLINE and EMBASE database was performed during December 2017. We included cross-sectional and cohort studies that reported relative risks (RR), odds ratios (OR) and hazard ratios (HR) comparing the risk of developing osteoporotic fractures among patients with CLD versus patients without CLD. Pooled OR and 95\% confidence interval (CI) were calculated using generic inverse- variance method. The Newcastle-Ottawa scale was used to determine the quality of the studies. Effect estimates from the individual study were extracted and combined using the random-effect, generic inverse variance method of DerSimonian and Laird.

\section{Results}

After the review of the literature, seven studies fulfilled the eligibility criteria established during the analysis. Significant association was found between CLD and osteoporotic fractures with a pooled OR of 2.13 ( $95 \%$ CI, $1.79-2.52)$. High heterogeneity among the studies was found (I2=88.5). No publication bias was found using Egger regression test $(\mathrm{p}=0.44)$.

\section{Conclusion}

Received 08/07/2020 Review began 08/18/2020 Review ended 09/09/2020 Published 09/16/2020

\section{() Copyright 2020}

Hidalgo et al. This is an open access article distributed under the terms of the Creative Commons Attribution License CC-BY 4.0., which permits unrestricted use, distribution, and reproduction in any medium, provided the original author and source are credited.
We found a significant association between CLD and the risk of developing osteoporotic fractures. The calculated risk was 2.13 times higher for patients with CLD when compared with controls. The results showed high heterogeneity but no publication bias. More prospective studies are needed to fully understand the mechanisms involved in loss of bone density and osteoporotic fractures in order to improve the morbidity associated with this disease.

Categories: Endocrinology/Diabetes/Metabolism, Internal Medicine, Gastroenterology Keywords: chronic liver disease, osteoporotic fractures, osteoporosis

\section{Introduction}

Chronic liver disease (CLD) is a progressive deterioration of liver function. It is shown through a process of worsening fibrosis and formation of regeneration nodules over a period of months. Initially the fibrosis may be reversible but, if not treated, it can lead to irreversible fibrosis, regeneration nodules formation and hence the development of cirrhosis [1]. The trend of chronic liver disease in the US is changing swiftly. Currently, it is the fourth leading cause of death in the US among adults 45 to 64 years old. According to the National Vital Statistics Report of 2017 from the Center for Disease Control and Prevention in the United States, approximately 4.5 million adults suffered from chronic liver disease and cirrhosis; which represents $1.8 \%$ of the adult population [2]. The rate of mortality from chronic liver disease and cirrhosis was 12.8 deaths per 100,000 population, equaling about 41,473 deaths in number [3].

The most common risk factors for chronic liver disease include excessive alcohol consumption, hepatitis B and C, obesity, diabetes mellitus, and metabolic syndrome [4]. Since the liver is an organ involved in various mechanisms of metabolism, chronic liver disease can lead to secondary osteoporosis which affects about $30 \%$ of patients suffering from this disease [5,6]. A number of factors are responsible for osteoporosis, 
including alteration in the metabolism of vitamin D and calcium, vitamin K deficiency, hormonal dysregulation, release of cytokines and deficiency of insulin-like growth factor 1 (IGF-1) [7]. Dysregulation of these processes may lead to disorders in bone homeostasis which can ultimately lead to osteopenia, osteoporosis and hence causing osteoporotic fractures [8].

Patients with confirmed chronic liver disease should be screened for osteoporosis as they are considered medium or high risk based of different factors. Serum vitamin D levels can also be obtained in order to correct the modifiable risk factors like calcium and vitamin D deficiency, smoking, alcohol abuse, and malnutrition [9]. The quality of the trabecular bone at the lumbar spine and hip can be obtained by densitometry tests. However, ascites can affect the densitometric accuracy of the tests by causing a fluid artifact that can falsely lower the bone mineral density measurements [10,11]. Many patients with osteoporosis go undiagnosed in the primary care clinic, mainly due to the lack of diagnostic tools. Multisite bone ultrasound methods are new tools that can potentially be used successfully in the future to diagnose low bone density, which can be more easily available in primary care settings [12].

The aim of this meta-analysis is to summarize the best evidence that correlates CLD patients and the risk of developing osteoporotic fractures versus control patients without CLD.

\section{Materials And Methods \\ Search strategy}

A review of the literature using MEDLINE and EMBASE database was performed during December 2017 by two investigators (DH and BB). The search strategy included terms and synonyms for "CLD," "osteoporosis," and "fractures."

This study meets the criteria checklist in accordance with the Preferred Reporting Items for Systematic Reviews and Meta-Analyses (PRISMA) statements.

\section{Selection criteria}

Any study, in order to be selected for this meta-analysis, had to fulfill the following parameters:

-Cross-sectional and cohort studies published by the two major databases used related to patients with CLD caused by cirrhosis, primary biliary cholangitis, and primary biliary cirrhosis. Subjects without CLD were used as comparators in cohort and cross-sectional study.

-Relative risks (RR), odds ratios (OR), and hazard ratios (HR) comparing the risk of developing osteoporotic fractures among patients with CLD versus patients without CLD.

-Pooled OR and 95\% confidence interval (CI) were calculated using generic inverse-variance method.

The Newcastle-Ottawa scale (Figure 1) was used by the investigators independently to determine the quality of each study. This scale evaluates each study in terms of participants selection (minimum score is 0 ; maximum is 4), comparability (minimum score is 0 ; maximum is 2), and the ascertainment of the exposure of interest for case-control studies, and the outcome of interest for cohort studies (minimum score is 0 ; maximum is 3) $[13,14,15]$. Newcastle-Ottawa scale contains eight items within three domains and the total maximum score is 9. A study with a score from 7-9 has high quality, 4-6, high risk, and 0-3 very high risk of bias [16]. Also, the effect estimates from the individual study were extracted and combined using the random-effect, generic inverse variance method of DerSimonian and Laird [17]. 


\section{Cureus}

\section{NEWCASTLE - OTTAWA QUALITY ASSESSMENT SCALE}

COHORT STUDIES

Note: A study can be awarded a maximum of one star for each numbered item within the Selection and Outcome categories. A maximum of two stars can be given for Comparability

\section{Selection}

1) Representativeness of the exposed cohort

a) truly representative of the average

b) somewhat representative of the average

c) selected group of users eg nurses, volunteers

d) no description of the derivation of the cohort

(describe) in the community $\star$

2) Selection of the non exposed cohort

a) drawn from the same community as the exposed cohort $\star$

b) drawn from a different source

c) no description of the derivation of the non exposed cohort

3) Ascertainment of exposure

a) secure record (eg surgical records) $\star$

b) structured interview $\star$

c) written self report

d) no description

4) Demonstration that outcome of interest was not present at start of study a) yes $\star$

b) no

Comparability

1) Comparability of cohorts on the basis of the design or analysis a) study controls for (select the most important factor) $\star$

b) study controls for any additional factor $\star$ (This criteria could be modified to indicate pecific control for a second important factor.)

Outcome

1) Assessment of outcome

a) independent blind assessment $\star$

b) record linkage $\star$

c) self report

d) no description

2) Was follow-up long enough for outcomes to occur

a) yes (select an adequate follow up period for outcome of interest) $\star$

b) no

3) Adequacy of follow up of cohorts

a) complete follow up - all subjects accounted for $\star$

b) subjects lost to follow up unlikely to introduce bias - small number lost -> $\quad \%$

(selectan adequate \%) follow up, or description provided of those lost) $\star$

c) follow up rate $<\ldots \%$ (select an adequate $\%$ ) and no description of those lost

d) no statement

FIGURE 1: Newcastle-Ottawa quality assessment scale

Adapted from [16].

\section{Data extraction}

The data collection used in this study was through the use of Microsoft Excel (Microsoft Corporation, Redmond, Washington, US) summarizing the most relevant information obtained from these studies. The characteristics included in these studies contained the first author's last name, country, study design, year of publication, demographics, total number of participants, characteristics of the participants, the method used to diagnose CLD, the method used to determine fractures, adjusted effect estimates with $95 \% \mathrm{CI}$, confounder adjustment and the Newcastle-Ottawa quality assessment scale (Table 1).

Table 1:

Characteristics

of studies

included

Chen et al. [18]

Country

Taiwan
Solaymani et al.

[19]

United Kingdom Taiwan
Tsai et al. [20] Bang et al. [21]

Denmark
Boulton et al. [22]

United Kingdom

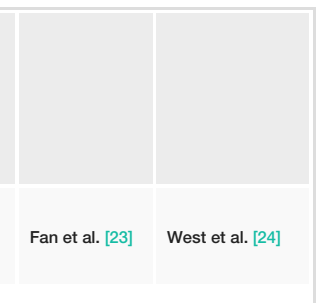

China

United Kingdom 


\section{Cureus}

\begin{tabular}{|c|c|c|c|c|c|c|c|}
\hline Study design & $\begin{array}{l}\text { Longitudianl Retrospective } \\
\text { Cohort study }\end{array}$ & $\begin{array}{l}\text { Population-Based } \\
\text { Cohort Study }\end{array}$ & $\begin{array}{l}\text { Nationwide } \\
\text { Population- } \\
\text { Based Study }\end{array}$ & $\begin{array}{l}\text { Retrospective Cohort } \\
\text { Study }\end{array}$ & Population Based Cohort Study & Meta analysis & $\begin{array}{l}\text { Population } \\
\text { Based Cohort } \\
\text { Study }\end{array}$ \\
\hline Year & 2017 & 2006 & 2012 & 2014 & 2004 & 2017 & 2010 \\
\hline $\begin{array}{l}\text { Number of } \\
\text { participants }\end{array}$ & 692,231 & 10,132 & 3764 & $\begin{array}{l}\text { Total: } 228459 ; 20,769 \\
\text { Patients with cirrhosis, } \\
\text { and } 207,690 \text { controls }\end{array}$ & $\begin{array}{l}\text { A total of } 201 \text { participants with } 85 \\
\text { PBC patients and } 116 \text { controls }\end{array}$ & $\begin{array}{l}1643 \text { PBC } \\
\text { patients and } \\
10921 \text { controls }\end{array}$ & $\begin{array}{l}\text { A total of } 4787 \\
\text { subjects with } \\
\text { cirrhosis and } \\
46,789 \\
\text { appropriately } \\
\text { matched } \\
\text { controls }\end{array}$ \\
\hline Participants & $\begin{array}{l}\text { The investigation included two } \\
\text { studies. Study I: } 3941 \text { adults } \\
\text { patients aged } \geq 20 \text { years in } \\
2000-2003 \text { with primary } \\
\text { diagnosis of cirrhosis of the liver } \\
\text { and at least two visits for } \\
\text { medical care frequency- } \\
\text { matching procedure (by age and } \\
\text { sex) with no previous medical } \\
\text { records of LC. Study II: } 688290 \\
\text { hospitalised patients with } \\
\text { fracture in } 2004-2013 \text { with a } \\
\text { history of LC within } 24 \text { months } \\
\text { pre-fracture. Thirty-day in- } \\
\text { hospital mortality, septicaemia, } \\
\text { and acute renal failure after } \\
\text { fracture were considered post- } \\
\text { fracture outcomes and were } \\
\text { compared in patients with } \\
\text { fracture with and without LC in } \\
\text { the nested fracture cohort } \\
\text { study. }\end{array}$ & $\begin{array}{l}930 \text { adults patients } \\
\text { aged } \geq 20 \text { years } \\
\text { with Primary } \\
\text { Biliary Cirrhosis } \\
\text { and } 9202 \text { controls } \\
\text { based in The } \\
\text { General Practice } \\
\text { Research } \\
\text { Database (GPRD) } \\
\text { between June } \\
1987 \text { and April } \\
2002\end{array}$ & $\begin{array}{l}4962 \mathrm{HE} \text { with } \\
\text { cirrhosis patients } \\
\text { over the 10-year } \\
\text { study period. } \\
\text { After excluding } \\
\text { patients } \\
\text { diagnosed at <20 } \\
\text { years of age ( } \mathrm{n}= \\
\text { 131) or who had } \\
\text { a fracture before } \\
\text { enrollment ( } \mathrm{n}= \\
1067 \text { ), the } \\
\text { sample } \\
\text { consisted of } \\
3764 \text { patients for } \\
\text { analysis. Patient } \\
\text { age ranged from } \\
20 \text { to } 100 \text { years, } \\
\text { with a median } \\
\text { age of } 53 y e a r s .\end{array}$ & $\begin{array}{l}\text { Patients diagnosed with } \\
\text { cirrhosis or CP were } \\
\text { identified from the Danish } \\
\text { National Patient Register. } \\
\text { Each patient was } \\
\text { matched to } 10 \text { age- and } \\
\text { sex-matched controls } \\
\text { using the Danish Civil } \\
\text { Registration System. For } \\
\text { both the cases and } \\
\text { controls, an event was } \\
\text { defined as any fracture } \\
\text { that happened in the } \\
\text { period from January } 1 \text {, } \\
1995 \text {, to December } 31 \text {, } \\
2010 .\end{array}$ & $\begin{array}{l}\text { Patients attending Nottingham } \\
\text { University and City Hospitals with } \\
\text { PBC were included. Patients who } \\
\text { had had a liver biopsy reported as } \\
\text { showing PBC or who had had a } \\
\text { raised antimitochondrial } \\
\text { immunoglobulin G (IgG) antibody } \\
\text { titre of greater than 1:50 on a } \\
\text { sample requested by a } \\
\text { gastroenterologist were identified } \\
\text { from a computerized pathology } \\
\text { database from } 1991 \text { to } 1999 \text { and } \\
\text { immunology database from } 1993 \\
\text { to } 1999 \text { respectively. A control } \\
\text { group of patients was identified } \\
\text { from the control series of a large } \\
\text { population-based case-control } \\
\text { study of myocardial infarction in } \\
\text { women previously conducted in } \\
\text { the same geographical area. }\end{array}$ & $\begin{array}{l}\text { Specific for } \\
\text { each article. } \\
\text { Does not } \\
\text { mention any } \\
\text { specific } \\
\text { number either } \\
\text { per article or } \\
\text { total. }\end{array}$ & $\begin{array}{l}\text { Patients with a } \\
\text { diagnostic of } \\
\text { therapeutic code } \\
\text { for cirrhosis, } \\
\text { esophageal } \\
\text { varices and/or } \\
\text { portal } \\
\text { hypertension } \\
\text { within the } \\
\text { General Practice } \\
\text { Research } \\
\text { Database=GPRD } \\
\text { between June } \\
1987 \text { and April } \\
2002 \text { and } \\
\text { records of up to } \\
10 \text { age-, sex and } \\
\text { practice } \\
\text { matched } \\
\text { controls. }\end{array}$ \\
\hline $\begin{array}{l}\text { Mean age of } \\
\text { participants }\end{array}$ & NA & NA & $\begin{array}{l}\text { median age of } 53 \\
\text { years old. }\end{array}$ & 56.6 years old & $\begin{array}{l}\text { cases: } 60.2 \text { years old; controls: } \\
59.7\end{array}$ & 55.9 years old & NA \\
\hline $\begin{array}{l}\text { Percentage of } \\
\text { females }\end{array}$ & Study I: $31.6 \%$, Study II: $34.6 \%$ & $88.30 \%$ & $34.30 \%$ & $35.50 \%$ & $100 \%$ & NA & NA \\
\hline $\begin{array}{l}\text { Diagnosis of } \\
\text { Chronic Liver } \\
\text { Disease }\end{array}$ & $\begin{array}{l}\text { Clinical records from the } \\
\text { Taiwan's National Health } \\
\text { Insurance Programme between } \\
2000-2003 \text { and 2004-2013 were } \\
\text { used in addition to ICD-9-CM } \\
\text { codes to identify patients' } \\
\text { medical conditions and } \\
\text { complications with Chronic } \\
\text { Liver Disease. }\end{array}$ & $\begin{array}{l}\text { The General } \\
\text { Practice Research } \\
\text { Database (GPRD) } \\
\text { were used to } \\
\text { extract the records } \\
\text { of all persons } \\
\text { between June } \\
1987 \text { and April } \\
2002 \text { with a } \\
\text { recorded } \\
\text { diagnosis of PBC } \\
\text { using OXMIS an } \\
\text { READ code. }\end{array}$ & $\begin{array}{l}\text { Based on ICD } 10 \\
\text { codes idetyfing } \\
\text { patient with a } \\
\text { diagnosis of } \\
\text { cirrhosis with } \\
\text { and without } \\
\text { hepatic } \\
\text { encephalopathy. }\end{array}$ & $\begin{array}{l}\text { Patients were included if } \\
\text { they had been discharged } \\
\text { with one of the } \\
\text { International } \\
\text { Classification of } \\
\text { Diseases, 10th edition } \\
\text { codes. Diagnosis of } \\
\text { alcoholic fibrosis and } \\
\text { sclerosis of liver, } \\
\text { alcoholic cirrhosis, } \\
\text { primary biliary cirrhosis, } \\
\text { secondary biliary } \\
\text { cirrhosis, biliary cirrhosis, } \\
\text { unspecified, autoimmune } \\
\text { hepatitis, and other } \\
\text { specified inflammatory } \\
\text { liver disease were } \\
\text { included. Viral cirrhosis } \\
\text { was not included in this } \\
\text { analysis. }\end{array}$ & $\begin{array}{l}\text { Case notes for the patients were } \\
\text { reviewed. For this study, a } \\
\text { diagnosis of PBC was made if two } \\
\text { of the following three criteria were } \\
\text { met: abnormal liver function tests } \\
\text { with a cholestatic pattern, a liver } \\
\text { biopsy report consistent with PBC } \\
\text { or positive antimitochondrial } \\
\text { antibodies. }\end{array}$ & $\begin{array}{l}\text { PBC used as } \\
\text { an exposure } \\
\text { factor. }\end{array}$ & $\begin{array}{l}\text { ICD } 10 \text { code for } \\
\text { cirrhosis, } \\
\text { esophageal } \\
\text { varices and } \\
\text { portal } \\
\text { hypertension. }\end{array}$ \\
\hline & & $\begin{array}{l}\text { Practice Research } \\
\text { Database (GPRD) } \\
\text { were used to }\end{array}$ & & $\begin{array}{l}\text { Fractures were identified } \\
\text { using the International } \\
\text { Classification of }\end{array}$ & & & \\
\hline
\end{tabular}




\section{Cureus}

\begin{tabular}{|c|c|c|c|c|c|c|c|}
\hline $\begin{array}{l}\text { Diagnosis of } \\
\text { Fractures }\end{array}$ & $\begin{array}{l}\text { Clinical records from the } \\
\text { Taiwan's National Health } \\
\text { Insurance Programme between } \\
\text { 2000-2003 and 2004-2013. ICD- } \\
\text { 9-CM codes were used to } \\
\text { identify patients' medical } \\
\text { conditions with different typyes } \\
\text { of fracture and injury included } \\
\text { skull, neck, trunk, upper and } \\
\text { lower limb fractures. }\end{array}$ & $\begin{array}{l}\text { extract the records } \\
\text { of all persons } \\
\text { between June } \\
1987 \text { and April } \\
2002 \text { with any } \\
\text { incident hip and } \\
\text { radius/ulna } \\
\text { fractures. In } \\
\text { addition to } \\
\text { potential } \\
\text { confounders: } \\
\text { height, weight, and } \\
\text { smoking habit, } \\
\text { drug exposures } \\
\text { (eg, oral and } \\
\text { injected } \\
\text { corticosteroids) } \\
\text { and } \\
\text { ursodeoxycholic } \\
\text { acid use. }\end{array}$ & $\begin{array}{l}\text { Based on ICD } 10 \\
\text { codes identyfing } \\
\text { patients with a } \\
\text { diagnosis of } \\
\text { fracture in the } \\
\text { skull, back, lower } \\
\text { or upper limbs. }\end{array}$ & $\begin{array}{l}\text { Diseases, } 10 \text { th edition } \\
\text { codes. Fractures of the } \\
\text { skull and facial bones, } \\
\text { cervical spine, thoracic } \\
\text { spine, ribs, pelvis, lumbar } \\
\text { spine, shoulder, humerus, } \\
\text { upper forearm, lower } \\
\text { forearm, wrist and hand, } \\
\text { proximal femur, lower } \\
\text { femur, lower leg, ankle, } \\
\text { foot, and,finally, } \\
\text { osteoporotic fracture } \\
\text { were included. Fractures } \\
\text { of the spine, humerus, } \\
\text { distal forearm, and } \\
\text { proximal femur were } \\
\text { considered as low-trauma } \\
\text { osteoporotic fractures. }\end{array}$ & $\begin{array}{l}\text { All PBC patients and controls were } \\
\text { sent a 9-page questionnaire } \\
\text { enquiring about their fracture } \\
\text { experience. }\end{array}$ & $\begin{array}{l}\text { Osteoporosis } \\
\text { or a fracture } \\
\text { as an } \\
\text { outcome }\end{array}$ & $\begin{array}{l}\text { ICD code for hip } \\
\text { and wrist } \\
\text { fractures }\end{array}$ \\
\hline $\begin{array}{l}\text { Adjusted } \\
\text { OR/HR/RR }\end{array}$ & $\begin{array}{l}\text { Study I: } \mathrm{HR} 1.83,95 \% \mathrm{Cl} 1.67 \text { to } \\
2.01 \text {, Study II: higher risks for } \\
\text { post-fracture sepsis (OR } 1.77 \text {, } \\
95 \% \mathrm{Cl} 1.60 \text { to } 1.96 \text { ), acute } \\
\text { renal failure (OR } 1.63,95 \% \mathrm{Cl} \\
1.33 \text { to } 1.99 \text { ), and } 30 \text {-day in- } \\
\text { hospital mortality (OR } 1.61,95 \% \\
\mathrm{Cl} 1.37 \text { to } 1.89 \text { ) were associated } \\
\text { with previous LC }\end{array}$ & $\begin{array}{l}\text { Risk of any } \\
\text { fracture: (HR: 2.04; } \\
95 \% \text { Cl: } 1.70- \\
2.44) \text { hip } \\
\text { fracture: (HR: } 2.14 \\
\text { (95\% Cl: } 1.40 \text { - } \\
\text { 3.28) ulna/radius } \\
\text { fracture: (HR: } 1.95 \\
(95 \% \mathrm{Cl}: 1.42- \\
2.69)\end{array}$ & $\begin{array}{l}\text { IRR } 1.63(95 \% \mathrm{Cl} \\
1.69-2.05, \mathrm{p}= \\
0.001)\end{array}$ & $\begin{array}{l}\text { The adjusted hazard ratio } \\
\text { (HR) for any fracture was } \\
2.4 \text { in patients with } \\
\text { cirrhosis }(95 \% \text { confidence } \\
\text { interval [Cl], 2.2-2.5) }\end{array}$ & $\begin{array}{l}\text { No statistically significant } \\
\text { increases in their risk of 'low } \\
\text { impact' fracture compared with } \\
\text { the general population (OR: } 1.0 \text {, } \\
95 \% \text { Cl: } 0.31-2.68 \text { ). Although the } \\
\text { overall bone fracture risk was } \\
\text { moderately increased (OR: } 1.5 \text {, } \\
95 \% \text { Cl: } 0.8-2.89 \text { ) this finding was } \\
\text { not statistically significant. }\end{array}$ & $\begin{array}{l}\text { PBC patients } \\
\text { had an OR of } \\
1.86(95 \% \mathrm{Cl} \\
1.54 \text { to } 2.24, \mathrm{P} \\
<0.00001)\end{array}$ & $\begin{array}{l}\text { Adjusted } \mathrm{HR} \text { for } \\
\text { fracture: } \\
\text { compensated } \\
\text { cirrhosis } 4.1 \\
(95 \% \mathrm{Cl} 3.0 \text { to } \\
5.40)\end{array}$ \\
\hline $\begin{array}{l}\text { Confounder } \\
\text { adjustment }\end{array}$ & $\begin{array}{l}\text { Multiple cox proportional hazard } \\
\text { and multiple logistic regression } \\
\text { models to control the } \\
\text { confounding effects of medical } \\
\text { conditions when investigating } \\
\text { the risks and outcomes of } \\
\text { fracture in patients with LC in } \\
\text { studies I and II were used. }\end{array}$ & $\begin{array}{l}\text { Cox regression to } \\
\text { estimate the } \\
\text { hazard ratios for } \\
\text { any fracture, hip } \\
\text { fracture, and } \\
\text { ulna/radius } \\
\text { fracture in the } \\
\text { PBC cohort } \\
\text { compared with the } \\
\text { general } \\
\text { population. }\end{array}$ & $\begin{array}{l}\text { Each HE patient } \\
\text { was matched } \\
\text { with one cirrhotic } \\
\text { patient without } \\
\text { HE and one non- } \\
\text { cirrhotic patient } \\
\text { (1:1:1) by age, } \\
\text { sex, and } \\
\text { comorbidities at } \\
\text { the same } \\
\text { enrollment date } \\
\text { [17]. The same } \\
\text { exclusion criteria } \\
\text { were applied to } \\
\text { both matched } \\
\text { cohorts. }\end{array}$ & $\begin{array}{l}\text { Univariate and } \\
\text { multivariate cox } \\
\text { proportional hazard } \\
\text { models to assess the } \\
\text { hazard ratio (HR) with } \\
95 \% \text { confidence interval } \\
\text { (Cl). Persons with missing } \\
\text { data were excluded from } \\
\text { the analyses. }\end{array}$ & $\begin{array}{l}\text { The cases and controls were } \\
\text { closely matched for common risk } \\
\text { factors for osteoporosis including } \\
\text { age, age of menarche and } \\
\text { menopause, use of hormone } \\
\text { replacement therapy (HRT). }\end{array}$ & $\begin{array}{l}\text { The different } \\
\text { studies were } \\
\text { matched for } \\
\text { age and } \\
\text { gender. }\end{array}$ & $\begin{array}{l}\text { They were } \\
\text { matched for age, } \\
\text { gender. }\end{array}$ \\
\hline $\begin{array}{l}\text { Quality } \\
\text { assessment } \\
\text { (Newcastle- } \\
\text { Otawwa scale) }\end{array}$ & $\begin{array}{l}\text { Selection: } 4 \text { Comparability: } 1 \\
\text { Outcome: } 3\end{array}$ & $\begin{array}{l}\text { Selection: } 4 \\
\text { Comparability: } 1 \\
\text { Outcome: } 3\end{array}$ & $\begin{array}{l}\text { Selection: } 3 \\
\text { Comparability: } 1 \\
\text { Outcome: } 3\end{array}$ & $\begin{array}{l}\text { Selection: } 4 \\
\text { Comparability: } 1 \\
\text { Outcome: } 3\end{array}$ & $\begin{array}{l}\text { Selection: } 2 \text { Comparability: } 1 \\
\text { Outcome: } 1\end{array}$ & $\begin{array}{l}\text { Selection: } 3 \\
\text { Comparability: } \\
1 \text { Outcome: } 3\end{array}$ & $\begin{array}{l}\text { Selection: } 3 \\
\text { Comparability: } 1 \\
\text { Outcome: } 2\end{array}$ \\
\hline
\end{tabular}

\section{TABLE 1: Characteristics of studies included}

PBC: Primary Biliary Cirrhosis, CP: Chronic Pancreatitis, HE: Hepatic Encephalopathy, LC: Liver Cirrhosis, ICD: International Classification of Diseases, HR: Hazard Ratio, OR: Odds Ratio, IRR, Cl: Confidence Interval, GPRD: General Practice Research Database.

All investigators performed the data extraction process independently to ensure accuracy. Any discrepancy in data was resolved by referring back to the original articles. 


\section{Statistical analysis}

Data analysis was performed using Review Manager 5.3 software from the Cochrane Collaboration (London, United Kingdom). Adjusted point estimates and standard errors from the individual studies were combined using the generic inverse variance method of DerSimonian and Laird, which assigned the weight of each study based on its variance [16]. In light of the possible high between-study variance due to different study designs and populations, we used a random-effect model rather than a fixed-effect model [15]. Cochran's $Q$ test and I2 statistic were used to determine the between-study heterogeneity. A value of I2 of $0 \%-25 \%$ represents insignificant heterogeneity, greater than $25 \%$ but less than or equal to $50 \%$ represents low heterogeneity, greater than $50 \%$ but less than or equal to $75 \%$ represents moderate heterogeneity, and greater than $75 \%$ represents high heterogeneity $[14,15]$.

\section{Results}

A total of 9986 articles were obtained. After excluding duplicates, a total of 2645 articles underwent title and abstract review. A total of 2604 articles were excluded, as they were case reports, book articles, letters to the editor, or review articles without the information needed for the analysis, leaving 50 for a full-length article review. A total of 42 articles were dismissed at this time because they did not have any comparators. An extra article was dismissed since it only included SD. A total of seven studies were used for statistical analysis; those studies were cohort, cross-sectional, and case-report studies. Those studies fulfilled the eligibility criteria established during the analysis. The outlines of the literature review and study selection process are given in Figure 2 . The clinical characteristics of each study and the quality assessment are described in Table 1 .

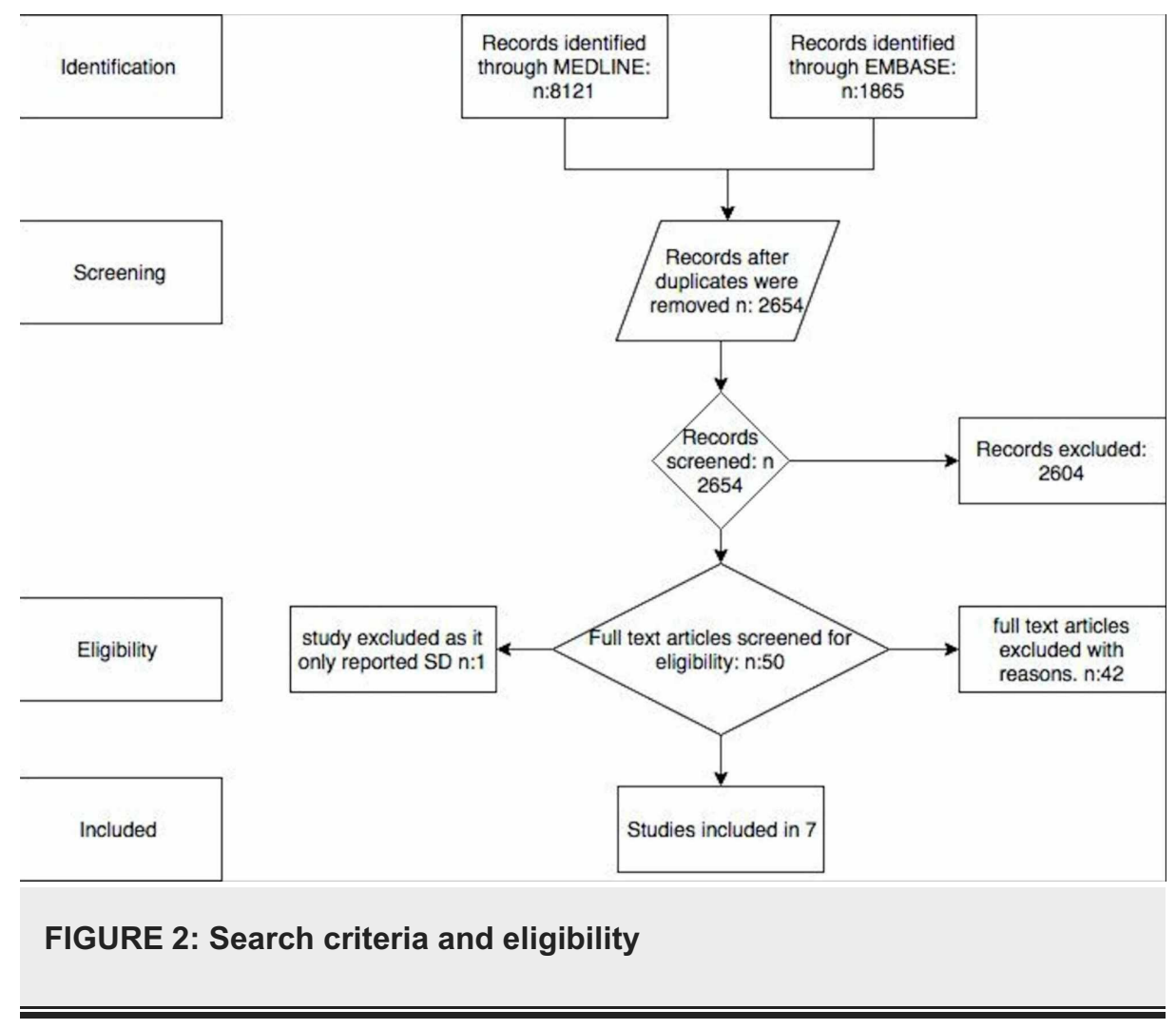

This study found an increased risk of osteoporotic fractures in patients with CLD vs patients who did not have CLD. Pooled odds ratio (OR) of 2.13 (95\% CI, $1.79-2.52$ ), $\mathrm{p}<0.001$, as shown in Figure 3. 


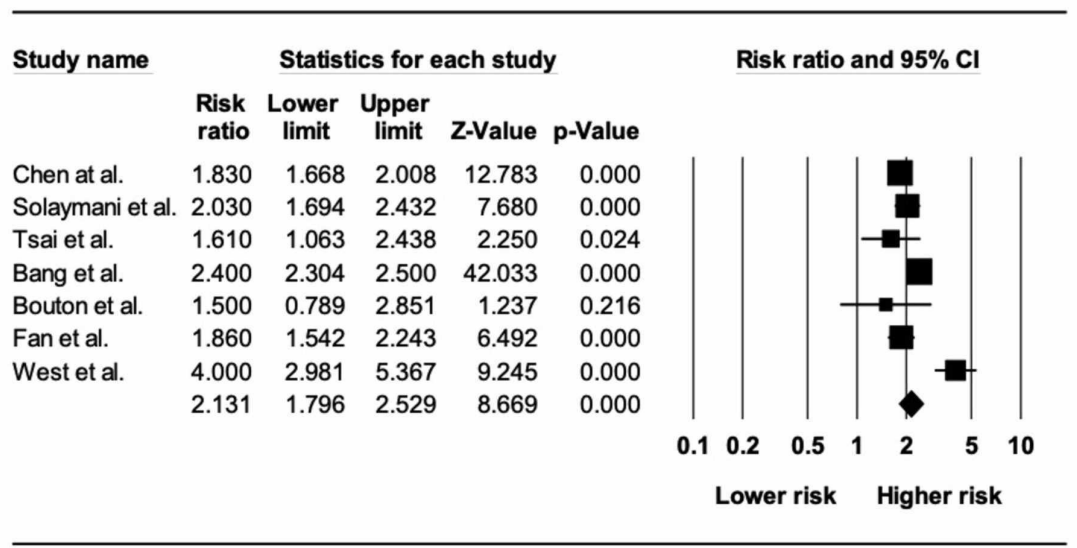

Meta Analysis

\section{FIGURE 3: Relative risk and P-value}

The Cochran's $Q$ test and I2 were calculated to measure the heterogeneity among the studies. The I2 calculated for this study was 88.5 , representing high heterogeneity among the studies. The Egger regression test and funnel plots were used to assess publication bias. Egger's regression test $(p=0.44)$ did not show a publication bias.

\section{Discussion}

This meta-analysis study was performed by the research team to assess the risk to develop osteoporotic fractures in patients diagnosed with chronic liver disease. After evaluating the seven studies that met the inclusion criteria, the calculated odds of developing an osteoporotic fracture in patients with CLD was found to be 2.13 times the odds of the controls who did not have CLD.

Our meta-analysis includes studies from around the world, such as Taiwan, United Kingdom, Denmark, and China with the involvement of more than 990,000 participants and their medical records [18-24]. Chen et al. reported that liver cirrhosis (LC) is an important risk factor for fracture with the adjusted HR of fracture being 1.83 (95\% CI 1.67 to 2.01), with more medical complications and 30-day in-hospital mortality after fracture [18]. Similarly, Solaymani et al. demonstrated that people with primary biliary cirrhosis (PBC) are approximately at a two-fold increased risk for any fracture in comparison with the general population [19]. Both of these studies were consistent with our findings (OR of 2.13; 95\% CI $1.79-2.52$ ) $[18,19]$. These results validate an association of CLD with osteoporotic fractures. In addition, all of our included studies had a satisfactory selection criteria and outcomes except the study done by Boulton et al., which had $100 \%$ females and therefore is an under-representation of the general population. Although it was the first study that had revealed the risk of osteoporosis in PBC patients, the sample size was not large enough and it was a selfreported questionnaire-based study. Because of this reason we scored it low on the outcomes.

Although the liver is involved in multiple metabolic pathways, the exact mechanism by which CLD can lead to osteoporotic fractures is not well understood. Liver disease leads to decreased formation of $25-\mathrm{OH}-$ vitamin D which causes impaired bone resorption, bone mineralization, and decreased calcium resorption in the gastrointestinal tract [7]. CLD causes increased concentrations of certain cytokines like interleukin (IL)1 , IL-6, and tumor necrosis factor $\alpha$ (TNF $\alpha$ ), thereby increasing the osteoclastic activity by stimulating the production of receptor activator of nuclear factor $\mathrm{kB}$ ligand (RANKL) [25,26]. Also, CLD can cause vitamin K deficiency which is an important vitamin for the synthesis of an osteoblast-specific protein, osteocalcin. Unconjugated bilirubin excess in the liver disease can also interfere with the activation of the primary osteoblasts to perform their function [26,27]. These are some of the mechanisms which can potentially cause osteoporosis in chronic liver disease leading to fractures [28].

A deeper understanding of the mechanisms described above could help the medical community to develop prophylactic and preventive measures. Finding different ways to modify risk factors and behaviors can decrease the negative effect that they have on healthy bone metabolism. By these means, we can improve the morbidity associated with osteoporotic fractures in patients with chronic liver disease.

Regarding the strengths of the study, it includes research studies done around the world with inclusion of over 990,000 patients. There was no publication bias found using the Egger regression test. Our study does have some limitations such as it included only observational studies. Also, only seven studies were eligible, out of which some were medical registry-based. The results showed high heterogeneity among these studies but there was no publication bias. We could not include a study by Patel 2009, as it reported only OR and SD. 
The result from Patel had very low SD, but unfortunately they did not report standard error.

More prospective studies are needed to better understand the mechanism of the risk factors in order to let us work more on preventive measures to decrease the morbidity associated with the fractures. Early detection and lifestyle modification could potentially decrease the risk of osteoporosis and hence the fractures in patients with CLD. This work has been presented as an abstract [29].

\section{Conclusions}

We found a significant association between CLD and the risk of developing osteoporotic fractures. The calculated risk was 2.13 times higher for patients with CLD when compared with controls. The results showed high heterogeneity but no publication bias. More prospective studies are needed to fully understand the mechanisms involved in loss of bone density and osteoporotic fractures in order to improve the morbidity associated with this disease.

\section{Additional Information \\ Disclosures}

Human subjects: All authors have confirmed that this study did not involve human participants or tissue. Animal subjects: All authors have confirmed that this study did not involve animal subjects or tissue. Conflicts of interest: In compliance with the ICMJE uniform disclosure form, all authors declare the following: Payment/services info: All authors have declared that no financial support was received from any organization for the submitted work. Financial relationships: All authors have declared that they have no financial relationships at present or within the previous three years with any organizations that might have an interest in the submitted work. Other relationships: All authors have declared that there are no other relationships or activities that could appear to have influenced the submitted work.

\section{References}

1. Heidelbaugh JJ, Bruderly M: Cirrhosis and chronic liver failure: part I. Diagnosis and evaluation . Am Fam Physician. 2006, 74:756-62.

2. Asrani SK, Larson JJ, Yawn B, Therneau TM, Kim WR: Underestimation of liver-related mortality in the United States. Gastroenterology. 2013, 145:375-82. 10.1053/j.gastro.2013.04.005

3. Sharma A, Nagalli S: Chronic Liver Disease. StatPearls, Treasure Island; 2020.

4. Flores YN, Zhang ZF, Bastani R, et al.: Risk factors for liver disease among adults of Mexican descent in the United States and Mexico. World J Gastroenterol. 2018, 24:4281-4290. 10.3748/wjg.v24.i37.4281

5. Guañabens N, Parés A: Management of osteoporosis in liver disease . Clin Res Hepatol Gastroenterol. 2011, 35:438-445. 10.1016/j.clinre.2011.03.007

6. Collier J, Ninkovic M, Compston J: Guidelines on the management of osteoporosis associated with chronic liver disease. Gut. 2002, 50:1-9. 10.1136/gut.50.suppl_1.11

7. Van Leeuwen J, van Driel M, van den Bemd G, Pols H: Vitamin D control of osteoblast function and bone extracellular matrix mineralization. Crit Rev Eukaryot Gene Expr. 2001, 11:199-226.

8. Handzlik-Orlik G, Holecki M, Wilczyński K, Duława J: Osteoporosis in liver disease: pathogenesis and management. Ther Adv Endocrinol Metab. 2016, 7:128-135. 10.1177/2042018816641351

9. Płudowski P, Karczmarewicz E, Bayer M, et al.: Practical guidelines for the supplementation of vitamin D and the treatment of deficits in Central Europe - recommended vitamin D intakes in the general population and groups at risk of vitamin D deficiency. Endokrynolog Pol. 2013, 64:319-327. 10.5603/ep.2013.0012

10. Guañabens N, Monegal A, Muxi A, et al.: Patients with cirrhosis and ascites have false values of bone density: implications for the diagnosis of osteoporosis. Osteoporos Int. 2012, 23:1481-1487. 10.1007/s00198-011-1756-1

11. Labio ED, Del Rosario DB, Strasser SI, McCaughan GW, Crawford BA: Effect of ascites on bone density measurement in cirrhosis. J Clin Densitom. 2007, 10:391-394. 10.1016/j.jocd.2007.07.001

12. Karjalainen J, Riekkinen O, Töyräs J, Jurvelin J, Kröger H: New method for point-of-care osteoporosis screening and diagnostics. Osteoporos Int. 2016, 27:971-977. 10.1007/s00198-015-3387-4

13. Stang A: Critical evaluation of the Newcastle-Ottawa scale for the assessment of the quality of nonrandomized studies in meta-analyses. Eur J Epidemiol. 2010, 25:603-605. 10.1007/s10654-010-9491-Z

14. Hidalgo DF, Boonpheng B, Phemister J, Hidalgo J, Young M: Inflammatory bowel disease and risk of osteoporotic fractures: a meta-analysis. Cureus. 2019, 11:5810-2019. 10.7759/cureus.5810

15. Hidalgo DF, Boonpheng B, Nasr L, Sikandar S, Hidalgo J, Intriago M: Celiac disease and risk of atrial fibrillation: a meta-analysis and systematic review. Cureus. 2020, 12:6997-2020. 10.7759/cureus.6997

16. Wells GA, Shea B, O'Connell D, Peterson J, Welch V, Losos M, Tugwell P: The Newcastle-Ottawa Scale (NOS) for assessing the quality of nonrandomised studies in meta-analyses. Ottawa Hospital Research Institute, Ottawa; 2014.

17. DerSimonian R, Laird N: Meta-analysis in clinical trials. Control Clin Trials. 1986, 7:177-178. 10.1016/01972456(86)90046-2

18. Chen TL, Lin CS, Shih CC, et al.: Risk and adverse outcomes of fractures in patients with liver cirrhosis: two nationwide retrospective cohort studies. BMJ Open. 2017:017342-2017. 10.1136/bmjopen-2017-017342

19. Solaymani-Dodaran M, Card TR, Aithal GP, West J: Fracture risk in people with primary biliary cirrhosis: a population-based cohort study. Gastroenterology. 2006, 131:1752-1757. 10.1053/j.gastro.2006.09.012

20. Tsai CF, Liu CJ, Chen TJ, et al.: Increased incidence of orthopedic fractures in cirrhotic patients: a nationwide population-based study. J Hepatol. 2013, 58:706-714. 10.1016/j.jhep.2012.12.001

21. Bang UC, Benfield T, Bendtsen F, Hyldstrup L, Beck Jensen J-E: The risk of fractures among patients with 


\section{Cureus}

cirrhosis or chronic pancreatitis. Clin Gastroenterol Hepatol. 2014, 12:320-326. 10.1016/j.cgh.2013.04.031

22. Boulton-Jones JR, Fenn RM, West J, Logan RF, Ryder SD: Fracture risk of women with primary biliary cirrhosis: no increase compared with general population controls. Aliment Pharmacol Ther. 2004, 20:551557. 10.1111/j.1365-2036.2004.02089.x

23. Fan J, Wang Q, Sun L: Association between primary biliary cholangitis and osteoporosis: meta-analysis . Clin Rheumatol. 2017, 36:2565-2571. 10.1007/s10067-017-3844-x

24. West, Asghar, Aithal, et al.: Increased risk of hip and wrist fracture in patients with cirrhosis compared with the general population: a population based- cohort study. 2010.

25. Nakchbandi IA: Osteoporosis and fractures in liver disease: relevance, pathogenesis and therapeutic implications. World J Gastroenterol. 2014, 20:9427-9438. 10.3748/wig.v20.i28.9427

26. Luxon BA: Bone disorders in chronic liver diseases . Curr Gastroenterol Rep. 2011, 13:40-48. 10.1007/s11894-010-0166-4

27. Goral V, Simsek M, Mete N: Hepatic osteodystrophy and liver cirrhosis. World J Gastroenterol. 2010, 16:1639-1643. 10.3748/wig.v16.i13.1639

28. López-Larramona G, Lucendo AJ, González-Castillo S, Tenias JM: Hepatic osteodystrophy: an important matter for consideration in chronic liver disease. World J Hepatol. 2011, 3:300-307. 10.4254/wih.v3.i12.300

29. Hidalgo DF, Boonpheng B, Phemister J, Young M: Chronic liver disease and the risk of osteoporotic fractures: a meta-analysis. Am J Gastroenterol. 2018, 113:S499-S500. 